"The impact of monetary policy transparency on inflation: the case of Ukraine"

$\begin{array}{ll} & \text { Serhiy Kozmenko iD https://orcid.org/0000-0001-7710-4842 } \\ \text { AUTHORS } & \text { Taras Savchenko } \\ & \text { Alona Zakutniaia }\end{array}$

ARTICLE INFO

Serhiy Kozmenko, Taras Savchenko and Alona Zakutniaia (2016). The impact of monetary policy transparency on inflation: the case of Ukraine. Banks and Bank Systems, 11(4), 82-89. doi:10.21511/bbs.11(4).2016.08

DOI $\quad$ http://dx.doi.org/10.21511/bbs.11(4).2016.08

RELEASED ON

Friday, 09 December 2016

JOURNAL

"Banks and Bank Systems"

FOUNDER

LLC "Consulting Publishing Company "Business Perspectives"

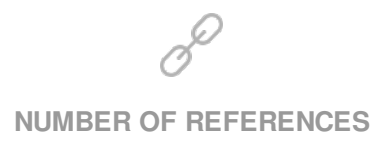

0

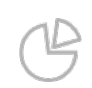

NUMBER OF FIGURES

0

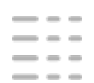

NUMBER OF TABLES

0

(C) The author(s) 2023. This publication is an open access article. 
Serhiy Kozmenko (Ukraine), Taras Savchenko (Ukraine), Alona Zakutniaia (Ukraine)

\title{
The impact of monetary policy transparency on inflation: the case of Ukraine
}

\begin{abstract}
This study presents empirical evidence on the impact of monetary policy transparency on inflation. A lot of studies analyzed how monetary policy transparency is entangled with inflation level from a theoretical point of view and came to contradictory results (some studies argued that transparency leads to lower inflation, others concluded that transparency results in higher prices). But this study is different from prior studies. Firstly, it looks at investigated issue empirically. Secondly, it considers for other causes of inflation and employs a panel data set on central bank transparency. Thirdly this paper investigates the issue associated with transparency in Ukraine. The authors find that transparency significantly reduces inflation rates in developed countries, but it is positively associated with inflation in Ukraine.
\end{abstract}

Keywords: central bank, monetary policy transparency, information disclosure, inflation.

JEL Classification: E52, E58, E59.

\section{Introduction}

Central banks used to be known for their secrecy, leaving people to guess their intentions. But, nowadays, most central banks announce their objectives with quantitative targets and publish numerical macroeconomic forecasts. They have also become much more open about their policy decisions and several ones even give explicit guidance about upcoming policy moves. Transparency has become a key feature of monetary policymaking and central banks consider it very important. Moreover, in the past ten years a number of countries have adopted inflation targeting. The key advantage of this strategy is that monetary policy is guided by a simple, logical criterion: the gap between forecasted and target inflation. Implementation of inflation targeting strategy by central bank is connected with public announcement of inflation targets and central bank's obligation to achieve these goals. The other reason why central banks became more transparent is that monetary policy transparency is desirable from an economic point of view. A plethora of studies shows that central banks openness is welfare enhancing and can lead to better economic outcomes. One question of the highest interest is how transparency and price stability are related. Experts of central banks, international financial organizations and scientists constantly emphasize that price stability is one of the main targets of practically every central bank. Nevertheless, there is no accord in the scientific literature regarding the impact of transparency on inflation. Also, only a few studies analyzes this relationship empirically. Thus, the

(c) Serhiy Kozmenko, Taras Savchenko, Alona Zakutniaia, 2016.

Serhiy Kozmenko, Dr., Professor of Department of Banking, Kharkiv National University of Economics, Ukraine.

Taras Savchenko, Dr., Professor, Head of the Chair of Accounting and Taxation, Education and research Institute for business technologies «UAB», Sumy State University, Ukraine.

Alona Zakutniaia, Assistant of the Chair of Finance, Banking and Insurance, Education and research Institute for business technologies «UAB», Sumy State University, Ukraine. aim of this paper is to investigate a comprehensive analysis of the effect of transparency on inflationin developed countries and in Ukraine.

\section{Literature review}

Mechanism of conducting monetary policy has undergone a dramatic transformation during the last two decades. Traditionally, central bank targets, objectives, institutional arrangements, policy models, forecasts, explicit strategy, minutes and policy decisions during previous decades had been considered as a subject to considerable secrecy. But, nowadays, most central banks have become much more open. As P.M. Geraats (2005) pointed, transparency has become a key feature of monetary policymaking and central banks consider it very important. This tendency could be partly explained by increase of central banks independent, which has been accompanied by formal accountability requirements.

P.M. Geraats (2005) based on comprehensive historical analysis, highlighted that growth of monetary policy transparency was realized in two phases. The first phase towards greater openness occurred during the 1990s, when central banks started to publish their analysis of macroeconomic developments and prospects in regular monetary policy reports. The second phase towards greater transparency have been implemented during the 2000 s. In this period, openness became more widespread. Emphasis on transparency in this period is based on the concept that monetary policy is very closely connected with "management" of people's expectations. That's why we can say that transparency and communication police of central bank are the hallmark of inflation targeting.

In the context of our study, according to the opinion of the ECB experts, transparency can be defined as an environment in which central bank provides general public and markets with all relevant information on its strategy, assessments and 
policy decisions, as well as its procedures, and does so in an open, clear and timely manner (European Central Bank, 2011).

Scientists identify four main characteristics of transparency, which include:

- accessibility (openness) of information - provision of information in the open access or at first request;

- completeness of information coverage - provision of sufficient volume of information to explain past and future actions of a central bank;

- timeliness - information should be provided with a minimum delay (including forecast for future);

- integrity of information - tools and channels of information policy should be consistent and coordinated with each other (Dincer, Eichengreen, 2014; Mishkin, 2004).

A number of empirical and theoretical studies show that central bank transparency has favorable effect on the inflation (Dincer, Eichengreen, 2014; Schaling, Nolan, 1998; Vinayagathasan, 2013). Some other papers, however, come to anopposite conclusion and find that either higher transparency is unfavorable or that it has an ambiguous effect at price stability.

Based on the analysis of the relevant economic literature, we have found out the absence of common approach to determination links between central bank transparency and inflation. Walsh, C.E. (1999), in his study, identifies that inflation levels can be lower in an inflation targeting countries. He notes that it is economically inefficient for central bank to deviate from inflation target, because individuals will increase their inflation expectations, thus, it will be expensive for the central bank to create surprise inflation. Only if financial market participants are not aware of supply shock, central bankers will mislead the public by saying that an unexpectedly high inflation rate was the result of a supply shock. However, according to Walsh, C.E. (1999), central banks that have adapted inflation targeting regime do not use this strategy.

Eijffinger S.C., Hoeberichts M. \& Schaling, E. (2000) for the first time, make a link between inflation and expectations of central bank employees. Authors argued that central banks with low transparency are perceived as less conservative. This fact leads to higher inflation via increased inflation expectations by employees. They also concluded that uncertainty about the central bank's preferences end up in higher inflation variability. A. Hughes Hallett \& J. Libich (2006) have made similar conclusion.
Geraats P.M. (2005) emphasizes that economic transparency is necessary for inflation stabilization. Thus, if the public is better informed about the central bank's economic forecasts, then, it can derive more meaningful conclusions from the actual monetary policy and make informed decisions about transactions in the financial markets.

On the other hand, there is a multitude of studies saying that central bank transparency is not always advantageous for maintaining price stability. J.R. Sørsensen (1991) concluded that political uncertainty (about the central bank's preferences towards output and inflation) leads to decrease in inflation. The reason is the fact that unions set lower nominal wages if the central bank's response to an increase in nominal wages is unclear.

A. Sibert (2002) was the first who demonstrated that concealing of information about central banks actions regarding key macroeconomic indicators are a necessary condition of market economy. Author avers that marker participants make decisions based only on their expectations. According to the signaling game, the central bank would like to pretend that it is conservative in order to reduce the welfare loss induced by the time-inconsistency problem. Thus, the central bank must conduct more restrictive monetary policy to be viewed as conservative.

In his study, A. Cukierman (2002) points out that monetary regulator, which does not announce economic models and goals is more likely to have a greater degree of market participants' confidence. If public are not fully rational, the publication of the economic model may increase inflation expectations in a situation, where the central bank has asymmetric preferences towards output and inflation stabilization.

So, there is no consensus with respect to the debate whether monetary policy transparency is positive in terms of stable prices or not. This opens the field for empirical analyses based on data investigation.

S.G. Cecchetti \& S. Krause (2002) investigated the influence of transparency on inflation. Scientists have analyzed the average inflation for the period 1995-1999 in 60 countries. Firstly, the researchers have used the approach of M. Fry (2000) for measuring the level of central banks transparency. Secondly, it was found negative correlation between transparency and average level of inflation. The next step was conducting a multivariate regression with the explanatory variables such as: independence, accountability, transparency, and credibility. As a result, it was found that even with the inclusion of additional variables, the relationship between inflation and transparency is negative. 
S. Morris \& H.S. Shin (2002) were the first to demonstrate that transparency influences economic outcomes through its effect on the formation of inflation expectations in what is known as coordination games. According to them, the central bank coordinates economic agent expectations through provision of information on how they (economic agents) are performing, as well as providing information on its (central bank) policy commitments. Furthermore, provide feedback on its own performance.

P.L. Siklos in (2003) made a study of 11 countries and concluded that central bank transparency leads to lower inflation expectations. The scientist used statistical indicators of 6 countries with a formal inflation targeting regime in practice and 5 that did not adopt inflation targeting. Simple dummy variable was created for the calculations ( 1 - inflation targeting regime was adopted; 0 - inflation targeting regime was not adopted).

Several studies (Crowe, Meade, 2007; Demertzis, Hallett, 2007) by using the Eijffinger-Geraats index (Eijffinger, Geraats, 2006) show that transparency has no impact on average inflation.

In the context of our study, research portfolio of G.E. Chortareas (2001) is interesting. The author used data on central bank transparency, calculated in 2000 by M. Fry (2000). Cross-country comparison of 87 countries and their average inflation rates from 1995 to 1999 was provided by G.E. Chortareas. He found a significant negative correlation between transparency and inflation. Furthermore, author conducted a multivariate analysis controlling for many other explanatory factors (e.g., political instability or whether a country has a fixed exchange rate). In this case, correlation between transparency and inflation is negative too.

B. Cournede \& M. Minegishi in (2009) estimated the impact of transparency on inflation expectations for 11 countries during period from 1999 to 2008 . They find that transparency has significantly negative influence on inflation expectations.

The most relevant is C.S. Weber's (2016) study, conducted in March 2016. The impact of number of factors on inflation was analyzed. The main feature of author's approach is to include a binary indicator "banking crisis", as well as indicators of the political situation in the country ("polity fragmentation", "political stability", "combined polity score"). The scientist concluded that increasing of monetary policy transparency leads to a decrease of inflation.

As a result of literature review we can make a conclusion about the availability of plethora of theoretical studies showing the causal relation between transparency of central banks and inflation. On the other hand, there have only been a few studies analyzing this relationship empirically. Thus, the aim of this paper is to analyze the effect of transparency on inflation with a large panel data set which considers inflation driving factors.

\section{Methodology}

Taking to account the abovedescribed literature, we can clarify objectives that were set out in the paper. The first one is to analyze the effect of transparency on inflation in developed countries (without Ukraine) by employing a panel data set. The second one is to determine whether the direction of relation between transparency and inflation in Ukraine is the same as in developed countries.

We used an algorithm that consists of four successive stages to solve these problems:

- identification of explanatory variables and testing them for unit roots;

- selection of the right model for estimating the relationship between monetary policy transparency and inflation on the example of developed countries;

- solution of potential endogeneity problems with respect to central bank transparency by using two stages fixed effects model;

- conducting a similar study on the example of Ukraine by building a multiple linear regression models.

So, first of all, we identified 25 explanatory variables which should be included in the estimation: monetary policy transparency, central bank independence, explicit inflation targeting, GDP growth, cereal production growth, crop production growth, food production growth, real interest rate, broad money growth, exchange rate growth, government accountability, trade (\% of GDP), political terror, political stability, government effectiveness, regulatory quality, rule of law, corruption control, bank deposits to GDP, government debt increase, government surplus/deficit, employment protection, union density. The data are mainly taken from the World Bank Development Indicators. We also used data from the Worldwide Governance Indicators, OECD and Political Terror Scale. Finally, we used the data of N.N. Dincer \& B. Eichengreen (2014) on central bank transparency and independence. The information about which countries have adopted Explicit Inflation Targeting was taken from G. Hammond (2010). The study was conducted in the context of 1998-2010 based on panel data for 20 countries. We used annual data for all variables. In this stage of study, Ukraine was not included in the list of countries because of two reasons. Firstly, data of the period 1998-2010 were not complex (a significant amount of data was missing), and secondly, the trend of economic development and the implementation of monetary 
policy in Ukraine during the study period were significantly different from other countries included in survey. All used variables were tested for unit roots (LLC-, B-, ADF-, APP-, IPS-tests) by using analytics software product EViews $v 7$. The result is that we are not plagued with non-stationary data.

The second step of our study was to choose the right model for estimating the relationship between monetary policy transparency and inflation. As a basic model, we offered to use a regression equation proposed by C.S. Weber (2016):

$p_{i t}=\vartheta_{i}+\tau_{t}+\beta_{0}+\sum_{k=1}^{m} \beta_{k} X_{k, i, t}+\varepsilon_{i t}$,

where $p_{i t}-$ inflation rate of country $i$ in year $t$; $\vartheta_{i}$ - country fixed effect; $\tau_{t}$ - time fixed effect; $\beta-\mathrm{K} \times 1$ column vector; $X_{i t}-\mathrm{a}$ row vector of explanatory variables of one particular observation scalar multiplied with the $\mathrm{K} \times 1$ column vector $\beta ; \varepsilon_{i t}$ - error of the regression.

The equation was estimated with OLS by using analytics software product EViews v7. We have run 13 regression equations to determine the degree and direction of the impact of monetary policy transparency on inflation.

On the third stage, we focused on potential endogeneity problems with respect to central bank transparency. Thus, there are two radically opposing points of view in the literature: on the one hand, scientists (Westelius, 2005) argue that it is central banks with low inflation rates that decide to increase their transparency; on the other hand (Rolnick, Weber, 1997), central banks with higher inflation rates increase their information provision with the aim of reducing inflation expectations. So, the results of our regression analysis are questionable, and we should conduct a more detailed investigation.

N. Dincer \& B. Eichengreen (2014) met a similar problem in 2014. They estimated the impact of transparency on GDP growth. Scientists proposed to use two stages fixed effects model, and to add additional (instrumental) exogenous variables to the regression equation. N. Dincer \& B. Eichengreen used variables of the World Governance Indictors, but some of these variables are directly correlated with inflation. In this context, the study of C.S. Weber (2016) is relevant. He found that the bank assets as a percentage of GDP are negatively correlated and freedom of the press is positively correlated with monetary policy transparency. However, these two variables are not directly correlated with inflation, which makes them good instruments.

We have decided only the first problem of analysis of the transparency impact on inflation. There is another - the problem of the relationship between inflation and the level of GDP. S. Kremer
(2013) found that output growth rates are lower if the inflation rate is higher than $2.5 \%$ in industrialized countries and $17 \%$ in developing countries. D. Baglan \& B. Yoldas (2014) argues that the threshold level for developing countries is around $12 \%$. T. Vinayagathasan (2013) proves that the threshold level for Asian countries is around $5.43 \%$. Because of the absence the consensus on the relationship between inflation and GDP, we could be plagued with reverse causality problems. In order to get rid of that issue, we could use an instrumental variable for GDP growth. We will take into account the study of C. Lee (2005), where the change in energy use (from World Development Indicators) is used as instrumental variable for GDP growth. We instrument for current and lagged GDP growth with current and lagged energy consumption growth.

So, in this step of our study, we estimated the effect of transparency on inflation by using two stages fixed effects model.

At the last (fourth) stage, we conducted a similar study on the example of Ukraine (taking into consideration the importance of indicators) by building a multiple linear regression models:

$p=\beta_{0}+\beta_{1} X_{1}+\beta_{2} X_{2}+\beta_{k} X_{k}$,

where $p$-inflation rate; $\beta_{1}-\beta_{k}$ - the regression parameters; $X_{1}-X_{2}-$ explanatory variables.

The equation was estimated with OLS by using analytics software product EViews v7. All time series of indicators was formed on an annual basis since 2002 ("The Main Principles of the Monetary Policy" was published at first time) to 2015. It is impossible to estimate retrospectively the level of monetary policy transparency, based on methodology of N. Dincer \& B. Eichengreen (2014). So, we have simplified transparency index, excluding from assessment methodology indicators, for which it is necessary to have timely information.

\section{Results}

According to the second step of estimation results, an increase in central bank transparency is associated with a significant decrease in the inflation rate (for any combination of independent variables in the regression equation). There is a significant negative relation between GDP growth and inflation. Real interest rates are negatively related to inflation. The exchange rate has the expected positive impact on inflation. We've already mentioned that there are several other factors that have an impact on inflation. Thus, central banks finance the public debt. This problem might especially arise when the government has difficulties with tax collection and seignioragebecomes an important source of government income. Results of regression 
analysis confirmed a positive relationship between inflation and the indicator "government debt increase", but this relationship is not statistically significant. As for the number of Worldwide Governance Indicators, the hypothesis of their influence on the inflation level was confirmed in most regression equations.

On the third stage of our study, we estimated the effect of transparency on inflation by using two stages fixed effects model. The F-statistics of the first stages show that the selected instruments are relevant. In the second stage, we ran six equations.
The coefficient on central bank transparency has a wider range when the 2SLS approach is used, but it is statistically significant in any instance. This puts more trust in the results. After proving an inverse relationship between the level of monetary policy transparency and inflation level based on panel data for 20 countries, we talked grounds for a similar study on the example of Ukraine. We have already mentioned that it is impossible to estimate retrospectively the level of monetary policy transparency, based on methodology of N. Dincer \& B. Eichengreen (2014). So, we have simplified transparency index (Table 1).

Table 1. The level of monetary policy transparency of the National Bank of Ukraine (simplified methodology)

\begin{tabular}{|c|c|c|c|c|c|c|c|c|c|c|c|c|c|c|c|}
\hline Evaluation criterion (indicator) & ઠิ & 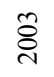 & ণ্ণ & ڤ్) & ¿্ণ & $\hat{\stackrel{d}{0}}$ & $\stackrel{\infty}{\stackrel{1}{े}}$ & ڤ્ণ & $\stackrel{\circ}{\stackrel{2}{c}}$ & $\overrightarrow{\bar{\sigma}}$ & $\stackrel{\sim}{\stackrel{\sim}{\sim}}$ & $\stackrel{m}{\vec{i}}$ & $\underset{\sim}{\vec{d}}$ & $\stackrel{n}{\stackrel{n}{c}}$ & $\stackrel{\circ}{\stackrel{\sim}{\sim}}$ \\
\hline \multicolumn{16}{|l|}{ 1. Political transparency } \\
\hline a. Formal objectives & 1 & 1 & 1 & 1 & 1 & 1 & 1 & 1 & 1 & 1 & 1 & 1 & 1 & 1 & 1 \\
\hline b. Quantitative targets & 1 & 1 & 1 & 1 & 1 & 1 & 1 & 1 & 1 & 1 & 1 & 1 & 1 & 1 & 1 \\
\hline c. Institutional arrangements & 0.5 & 0.5 & 0.5 & 0.5 & 0.5 & 0.5 & 0.5 & 0.5 & 0.5 & 0.5 & 0.5 & 0.5 & 0.5 & 0.5 & 0.5 \\
\hline \multicolumn{16}{|l|}{ 2. Economic transparency } \\
\hline a. Economic data & 0 & 0 & 0 & 0 & 0.5 & 0.5 & 0.5 & 0.5 & 1 & 1 & 1 & 1 & 1 & 1 & 1 \\
\hline b. Policy models & 0 & 0 & 0 & 0 & 0 & 0 & 0 & 0 & 0 & 0 & 0 & 0 & 0 & 0 & 0 \\
\hline c. Central bank forecasts & 0 & 0 & 0 & 0 & 0 & 0 & 0 & 0 & 0.5 & 0.5 & 0.5 & 0.5 & 0.5 & 0.5 & 0.5 \\
\hline \multicolumn{16}{|l|}{ 4. Policy transparency } \\
\hline 4.1 Prompt announcement & 0 & 0 & 0 & 0 & 0 & 0 & 0 & 0 & 0 & 0 & 0 & 0 & 0 & 0.5 & 1 \\
\hline 4.2 Policy inclination & 0 & 0 & 0 & 0 & 0 & 0 & 0 & 0 & 0 & 0 & 0 & 0 & 0 & 0 & 0 \\
\hline \multicolumn{16}{|l|}{ 5. Operational transparency } \\
\hline a. Control errors & 0.5 & 0.5 & 0.5 & 0.5 & 0.5 & 0.5 & 0.5 & 0.5 & 1 & 1 & 1 & 1 & 1 & 1 & 1 \\
\hline b. Transmission disturbances & 0 & 0 & 0 & 0 & 0 & 0 & 0 & 0 & 0 & 0 & 0 & 0 & 0 & 0.5 & 0.5 \\
\hline c. Evaluation policy outcome & 0 & 0 & 0 & 0 & 0 & 0 & 0 & 0 & 0 & 0 & 0 & 0 & 0 & 0 & 0 \\
\hline Total & 3 & 3 & 3 & 3 & 3.5 & 3.5 & 3.5 & 3.5 & 5 & 5 & 5 & 5 & 5 & 6 & 6.5 \\
\hline
\end{tabular}

Note: the cut-off date 01.09.2016.

The group of indicators "Procedural transparency" was excluded due to the fact that disclosure of this information is operational, so, it is difficult to follow it retrospectively. For the same reason, we excluded the indicator "Policy Explanation" of the group "Policy transparency" (comments of representatives of the National Bank of Ukraine on an occasional basis are published on the official website and on the page in Facebook).

After that, we have run six regression equations (Table 2) to determine the degree and direction of the impact of monetary policy transparency on inflation in Ukraine.

Firstly, we determined the key factors that have impact on inflation: GDP growth, cereal production growth, real interest rate, broad money growth andexchange rate growth (including the lagged values of these indicators). Then, indicator "monetary policy transparency" was included. There is a significant direct relationship between inflation level and monetary policy transparency level. But, as mentioned earlier, factors which characterize the political environment in the country should be considered in regression model. Therefore, in steps 3 and 4 (Table 2), we included indicators of governance quality (political stability, government effectiveness, corruption control) to the model, at the same time excluded a number of macroeconomic indicators (cereal production growth, real interest rate (t-1), broad money growth ( $t-1)$ and exchange rate growth (t-1)), that, according to the results of preliminary assessment, have insignificant impact on inflation. So, inflation has direct statistically significant relationship with transparency level and inverse relationship with political stability. 
Table 2. Determinants of inflation in Ukraine (static characteristics of multivariate regression equation)

\begin{tabular}{|c|c|c|c|c|c|c|}
\hline \multirow{2}{*}{ Variable } & \multicolumn{6}{|c|}{ Number of regression equation (steps of analysis) } \\
\hline & 1 & 2 & 3 & 4 & 5 & 6 \\
\hline monetary policy transparency & & $0.148^{*}$ & $0.159^{*}$ & $0.123^{\star}$ & $0.130^{*}$ & $0.122^{*}$ \\
\hline central bank independence & & & & 0.574 & & \\
\hline GDP growth & $-0.649^{\star}$ & $-0.028^{\star}$ & $-0.019^{*}$ & $-0.018^{*}$ & $-0.212^{*}$ & $-0.126^{*}$ \\
\hline GDP growth $(\mathrm{t}-1)$ & $0.155^{* \star *}$ & $0.022^{* *}$ & $0.012^{*}$ & & & \\
\hline cereal production growth & $-0.191^{\star \star \star}$ & 0.031 & & & & \\
\hline cereal production growth (t-1) & $-0.394^{\star}$ & $0.047^{\star \star}$ & $-0.022^{\star \star \star}$ & $-0.115^{\star \star \star}$ & $-0.064^{\star *}$ & $-0.062^{* *}$ \\
\hline real interest rate & $-0.501^{*}$ & $-0.035^{*}$ & $-0.007^{*}$ & -0.176 & $-0.142^{*}$ & $-0.145^{*}$ \\
\hline real interest rate $(\mathrm{t}-1)$ & 0.021 & $0.007^{\star}$ & & & & \\
\hline broad money growth & $0.355^{*}$ & $0.023^{*}$ & 0.164 & 0.156 & & \\
\hline broad money growth (t-1) & 0.081 & 0.001 & & & & \\
\hline exchange rate growth & $0.437^{\star}$ & $0.111^{* \star}$ & 0.215 & $0.002^{\star \star}$ & 0.011 & \\
\hline exchange rate growth (t-1) & 0.094 & $0.040^{*}$ & & & & \\
\hline political stability & & & $-0.008^{* \star *}$ & $-0.083^{*}$ & $-0.043^{* *}$ & \\
\hline government effectiveness & & & 0.004 & 0.102 & & \\
\hline corruption control & & & -0.220 & -0.268 & & \\
\hline Constant & $1.881^{*}$ & $1.563^{\star}$ & $1.299^{*}$ & $0.832^{*}$ & $1.405^{\star}$ & $1.418^{\star}$ \\
\hline R-squared & 0.994 & 0.998 & 0.996 & 0.997 & 0.985 & 0.981 \\
\hline Adjusted R-squared & 0.973 & 0.998 & 0.983 & 0.988 & 0.973 & 0.973 \\
\hline F-statistic & 50.640 & 61.365 & 60.889 & 63.01 & 51.049 & 61.69 \\
\hline Prob (F-statistic) & 0.004 & 0.000 & 0.002 & 0.001 & 0.000 & 0.000 \\
\hline
\end{tabular}

Note: the asterisks indicate whether a coefficient is significantly different from zero at the $10 \%$ (three asterisks), $5 \%$ (two asterisks) or $1 \%$ (one asterisk) significance level.

At the last stage (step 6), excluding all statistically insignificant independent variables, we have built the following equation:

$$
\begin{aligned}
p= & 0,122 T R-0,126 G D P-0,062 C P_{t-1}- \\
& -0,145 R I R+1,418,
\end{aligned}
$$

where $p$ - inflation rate; $T R$ - monetary policy transparency level; $G D P$ - GDP growth; $C P_{t-1}-$ cereal production growth (t-1); RIR - real interest rate.

Our regression model (equation 3) confirms the presence of an inverse relationship between inflation and most of indicators. The inflation level has weak relationship with cereal production growth (t-1) and moderate relationship with GDP growth and monetary policy transparency level. Real interest rate has the most significant indirect impact on the inflation. So, regarding the influence of monetary policy transparency on inflation level the hypothesis of inverse impact was refuted. For Ukraine, the increase in transparency leads to inflation rise.

In our view, this trend is quite natural and is caused by a number of factors:

- underdevelopment of market institutions, a significant level of state involvement in economic processes, monopolization of the economy;

- the presence of the shadow economy, which has an impact on almost all real macroeconomic indicators;

- quite high "cost of information openness";
- shortcomings in information exchange (except the National Bank of Ukraine, there are other information providers who interpret the official data, based on their interests);

- growing mistrust among market participants and the National Bank of Ukraine;

- low financial literacy;

- unwillingness (inability) to use the official site of the National Bank for information on the money market in order to obtain information about money market.

It should be noted that there is similar situation in most developing countries. The scientists (Grüner, 2002; Mishkin, 2004; Sibert, 2002; Sørsensen, 1991) argue that this trend is not causal; it only shows the necessity of creation an integrated approach to the monetary policy system transformation in which measures are aimed at reforming the central bank and monetary system.

Nowadays measures aimed at reforming the central bank and monetary policy system are implemented in Ukraine. The main components of these reforms are: the new structure of the monetary policy (strengthening the political and operational independence of the NBU, development by NBU its own inflation forecast), introduction of market instruments of interest rate control, implementation of the new monetary strategy, changes in the organization structure of the National Bank of Ukraine, expansion of communication channels (activation of 
Internet communication channel). So, the direction of transparency impact on inflation level will change from direct to inverse on conditions of successful implementation of the monetary policy reforms strategy and ensuring a favorable social and political climate in the country (political stability, government effectiveness, corruption control).

\section{Conclusion}

This work studies the relationship between monetary policy transparency and inflation level. The literature review clearly showed the availability of plethora of theoretical studies showing the causal association between transparency of central banks and inflation. But there is luck of comprehensive approach regarding the degree and direction of this relationship. Some papers argued that transparency should have a dampening effect on prices. On the other hand, there is a multitude of studies saying that central bank transparency is not always advantageous for maintaining price stability and transparency leads to higher inflation rates. Only a few studies analyzing this relationship empirically. One of the major problems was that these papers did not take other causes of inflation into account. The most relevant in this case is C.S. Weber (2016) study. The main feature of authors approach is to include a binary indicator "banking crisis", as well as indicators of the political situation in the country ("polity fragmentation", "political stability", "combined polity score"). The scientist concluded that increas- ing of monetary policy transparency leads to a decrease in inflation. There are no studies that figure out the impact of monetary policy openness in Ukraine. Therefore, we have set ourselves the task of comparative analyzing the effect of transparency on inflation in developed countries and in Ukraine.

First of all, we collected a panel data set to investigate the impact of monetary policy transparency while controlling for other inflation causes at the same time. Within a fixed effects model, a significant negative effect of transparency on inflation was proved (based on an example the developed countries). Then, we did some robustness checks by employing two stages least squares approach. Even under these circumstances a diminishing effect of monetary policy transparency on prices was proved. Finally, we employed a similar study on the example of Ukraine by building a multiple linear regression model. However, regarding the influence of monetary policy transparency on inflation level the hypothesis of inverse impact was refuted (for Ukraine, the increase in transparency leads to inflation rise). This result was explained by low level of trust between money market participants and the National Bank of Ukraine and also by macroeconomic imbalances in country. In our opinion, when these problems will overcome, inverse relation between inflation and monetary policy transparency that was theoretically (and practically for developed countries) improved in this paper could appear in Ukraine economy.

\section{References}

1. Baglan, D. \& Yoldas, E. (2014). Non-linearity in the inflation-growth relationship in developing economies: Evidence from a semiparametric panel model, Economics Letters, 125 (1), pp. 93-96.

2. Cecchetti, S.G. \& Krause, S. (2002). Central bank structure, policy efficiency, and macroeconomic performance: exploring empirical relationships, Federal Reserve Bank of St. Louis Review, 84 (July/August 2002).

3. Chortareas, G.E., Stasavage, D. \& Sterne, G. (2001). Does it pay to be transparent? International evidence from central bank forecasts, Bank of England Working Paper, p. 143.

4. Cournede, B. \& Minegishi, M. (2009). The role of transparency in the conduct of monetary policy (No. 724). OECD Economics Department Working Paper.

5. Crowe, C. \& Meade, E.E. (2007). The evolution of central bank governance around the world, The Journal of Economic Perspectives, 21 (4), pp. 69-90.

6. Cukierman, A. (2002). Are contemporary central banks transparent about economic models and objectives and what difference does it make? Federal Reserve Bank of St. Louis Review, 84 (July/August 2002).

7. Demertzis, M. \& Hallett, A.H. (2007). Central bank transparency in theory and practice, Journal of Macroeconomics, 29 (4), pp. 760-789.

8. Dincer, N.N. \& Eichengreen, B. (2014). Central Bank Transparency and Independence: Updates and New Measures, International Journal of Central Banking, 10 (1), pp. 189-259.

9. Eijffinger, S.C. \& Geraats, P.M. (2006). How transparent are central banks? European Journal of Political Economy, 22 (1), pp. 1-21.

10. Eijffinger, S.C., Hoeberichts, M. \& Schaling, E. (2000). Why money talks and wealth whispers: Monetary uncertainty and mystique, Journal of Money, Credit and Banking, pp. 218-235.

11. Fatas, A., Mihov, I. \& Rose, A.K. (2007). Quantitative goals for monetary policy, Journal of Money, Credit and Banking, 39 (5), pp. 1163-1176.

12. Frankel, J.A. (2011). Monetary Policy in Emerging Markets, Vol. 3B. In: Friedman, B. M., \& Woodford, M. (Eds.). (2010). Handbook of Monetary Economics, Vol. 3B. Elsevier, pp. 1439-1520.

13. Fry, M., Julius, D., Mahadeva, L., Roger, S. \& Sterne, G. (2000). Key issues in the choice of monetary policy framework. Monetary policy frameworks in a global context, London: Routledge, pp. 2-18. 
14. Gasiorowski, M.J. (2000). Democracy and Macroeconomic Performance in Underdeveloped Countries An Empirical Analysis, Comparative Political Studies, 33 (3), pp. 319-349.

15. Geraats, P.M. (2005). Transparency and reputation: The publication of central bank forecasts, Topics in Macroeconomics, 5 (1).

16. Gruben, W.C. \& McLeod, D. (2002). Capital account liberalization and inflation, Economics Letters, 77 (2), pp. 221-225.

17. Grüner, H.P. (2002). How much should central banks talk? A new argument, Economics Letters, 77 (2), pp. 195-198.

18. Hammond, G. (2010). State of the Arte of Inflation Targeting, In Bank of England. CCBS Handbook.

19. Hayo, B. (1998). Inflation culture, central bank independence and price stability, European Journal of Political Economy, 14 (2), pp. 241-263.

20. Hughes Hallett, A. \& Libich, J. (2006). Central Bank Independence, Accountability and Transparency: Complements or Strategic Substitutes? (No. 5470). CEPR Discussion Papers.

21. Kremer, S., Bick, A. \& Nautz, D. (2013). Inflation and growth: new evidence from a dynamic panel threshold analysis, Empirical Economics, 44 (2), pp. 861-878.

22. Lee, C.C. (2005). Energy consumption and GDP in developing countries: a cointegrated panel analysis. Energy Economics, 27 (3), pp. 415-427.

23. Levin, A.T., Natalucci, F.M. \& Piger, J.M. (2004). The macroeconomic effects of inflation targeting, Federal Reserve Bank of St. Louis Review, 86 (July/August 2004).

24. Mishkin, F.S. (2004). Can central bank transparency go too far? (No. w10829). National Bureau of Economic Research.

25. Morris, S and Shin, H.S. (2002). Social Value of Public Information, The American Economic Review, 92 (5).

26. Rolnick, A.J. \& Weber, W.E. (1997). Money, inflation, and output under fiat and commodity standards, Journal of Political Economy, 105 (6), 1308-1321.

27. Sachsida, A., Carneiro, F.G. \& Loureiro, P.R. (2003). Does greater trade openness reduce inflation? Further evidence using panel data techniques, Economics Letters, 81 (3), pp. 315-319.

28. Schaling, E. \& Nolan, C. (1998). Monetary policy uncertainty and inflation: The role of central bank accountability, The Economist, 146 (4), pp. 585-602.

29. Sibert, A. (2002). Monetary policy with uncertain central bank preferences, European Economic Review, 46 (6), pp. 1093-1109.

30. Siklos, P.L. (2003). Assessing the Impact of Changes in Transparency and Accountability at the Bank of Canada, Canadian Public Policy/Analyse de Politiques, pp. 279-299.

31. Sørsensen, J.R. (1991). Political uncertainty and macroeconomic performance. Economics Letters, 37 (4), pp. 377-381.

32. The Monetary Policy of the ECB. (2011). European Central Bank.

33. Vinayagathasan, T. (2013). Inflation and economic growth: A dynamic panel threshold analysis for Asian economies, Journal of Asian Economics, 26, pp. 31-41.

34. Walsh, C.E. (1999). Announcements, inflationtargetingand central bank incentives, Economica, 66 (262), pp. 255 269.

35. Weber, S.C. (2016). Central Bank Transparency and Inflation (Volatility) - New Evidence (No.163). BGPE Discussion Paper.

36. Westelius, N.J. (2005). Discretionary monetary policy and inflation persistence, Journal of Monetary Economics, 52 (2), pp. 477-496.

37. Yorukoglu, M. (2010). Difficulties in inflation measurement and monetary policy in emerging market economies, BIS Papers, 49, pp. 369-389. 